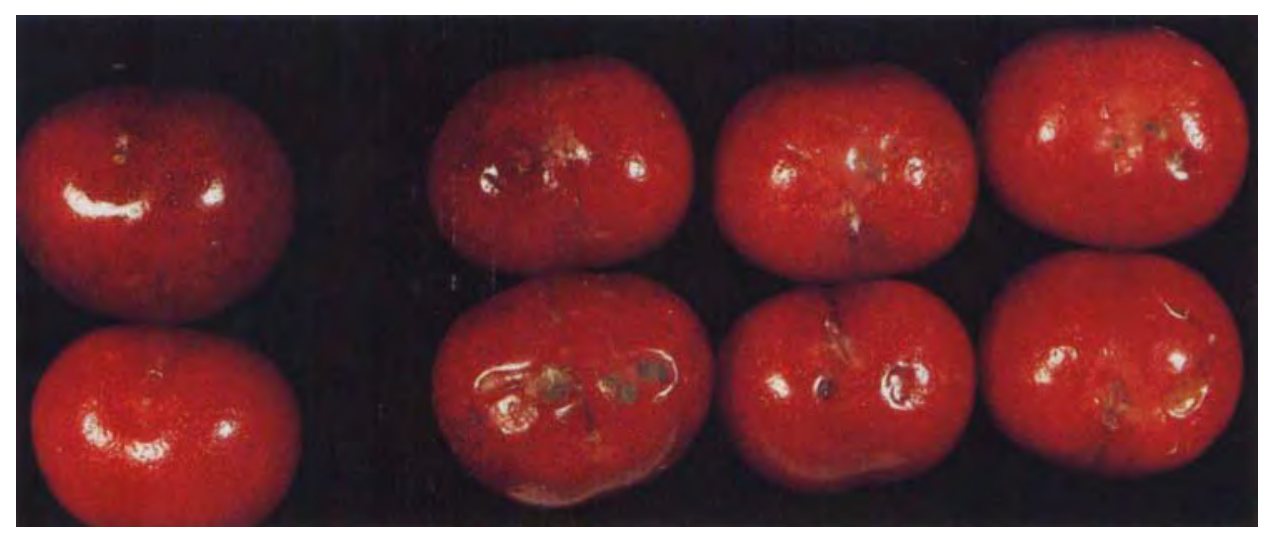

The six 'Brooks' cherries on the right exhibit symptoms of pitting. Cherries handled at colder temperatures suffer more pitting and bruising damage.

\title{
Cold 'Brooks' cherries suffer more pitting and bruising
}

\author{
Carlos H. Crisosto a Harry Andris a Kevin R. Day $\square$ David Garner
}

\begin{abstract}
The incidence of pitting and impact bruising on 'Brooks' sweet cherries was greatest when the flesh temperature was near $1^{\circ} \mathrm{C}$ $\left(34^{\circ} \mathrm{F}\right)$, intermediate near $10^{\circ} \mathrm{C}$ $\left(50^{\circ} \mathrm{F}\right)$, and lowest near $20^{\circ} \mathrm{C}$ $\left(68^{\circ} \mathrm{F}\right)$. Therefore 'Brooks' cherries should be handled at temperatures between $10^{\circ}$ and $20^{\circ} \mathrm{C}$ $\left(50^{\circ}\right.$ and $\left.68^{\circ} \mathrm{F}\right)$ during packing to minimize surface damage. However, because of increased respiration rates at higher temperatures, cherries should be cooled to $0^{\circ} \mathrm{C}\left(32^{\circ} \mathrm{F}\right)$ within 4 to 6 hours of harvest.
\end{abstract}

The incidence of bruising and pitting (surface damage) limits shelf life in cherries by inducing rapid softening and decay and reduces consumer acceptance. Surface damage can result when fruit are dropped onto a hard surface, onto other fruit, or onto stems. The incidence of surface damage is positively correlated with the height of free fall, texture of the contact surface, and flesh temperature. Cherries that are cold at the time of the impact are more susceptible to bruising and pitting than warm cherries.

To develop postharvest temperature-management strategies to prolong the shelf life of 'Brooks' cherries (Prunus avium L.), it is necessary to understand the influence of temperature on surface damage susceptibility and respiration rate. Most pitting and bruising studies have been conducted on 'Bing,' 'Lambert' and 'Van' cherries grown under mild temperature conditions, so we decided to study the relationship between flesh temperature and pitting of 'Brooks' sweet cherries grown in the warmer temperatures of the southern San Joaquin Valley. We also compared the respiration rates of 'Bing' with 'Brooks,' 'King' and 'Tulare' cherries.

\section{Temperature, surface damage}

To study the relationship between temperature and surface damage in 'Brooks' cherries, we used $2.1 \mathrm{~cm}$ diameter fruit (size row 12) during two years, 1991 and 1993. During the 1991 season, 'Brooks' (harvested May 20),
'Tulare' (harvested May 22), 'King' (harvested May 29) and 'Bing' (harvested June 5) cherries growing in the Fresno area were harvested at commercial maturity, as determined by solid, bright red skin color. During the 1993 season, 'Brooks' cherries were harvested in the Fresno area at the bright red color (May 20) and at the mahogany color (May 25). The cherries were transported to the F. Gordon Mitchell postharvest facilities at the Kearney Agricultural Center in Parlier within 2 hours of harvest and hydrocooled until the desired flesh temperature for each fruit was reached.

Respiration rate. $\mathrm{CO}_{2}$ production for 'Brooks,' 'Bing,' 'King' and 'Tulare' cherries, with pedicels attached, was measured at $0^{\circ}, 5^{\circ}, 10^{\circ}$ and $20^{\circ} \mathrm{C}\left(32^{\circ}\right.$, $41^{\circ}, 50^{\circ}$ and $\left.68^{\circ} \mathrm{F}\right)$. Cherries from each cultivar were enclosed in glass jars that were ventilated with air at a flow rate sufficient to avoid $\mathrm{CO}_{2}$ accumulation above $0.3 \%$. Samples were allowed to equilibrate for 24 hours, and the generated $\mathrm{CO}_{2}$ was then measured with a Horiba PIR-2000R gas analyzer. 
Fruit damage. To study the relationship between temperature and surface damage, 'Brooks' cherries, with pedicels attached, at $0^{\circ}, 10^{\circ}, 20^{\circ}$ and $24^{\circ} \mathrm{C}\left(32^{\circ}, 50^{\circ}, 68^{\circ}\right.$ and $\left.76^{\circ} \mathrm{F}\right)$ flesh temperature, were dropped stem end up from a height of $45 \mathrm{~cm}$ (17.7 inches) through a vertical PVC pipe $(2.6 \mathrm{~cm}$ inside diameter) onto a slanted metal plate (1991 season). For the 1993 season, 'Brooks' cherries, with pedicels, at $1^{\circ}, 7^{\circ}$ and $26^{\circ} \mathrm{C}\left(34^{\circ}, 44^{\circ}\right.$, and $\left.78^{\circ} \mathrm{F}\right)$, were dropped stem end up from a height of $7.5 \mathrm{~cm}$ (3.0 inches) onto a dimple belt instead of a metal plate. When dropped through the PVC pipe, the cherries with pedicels were not able to tumble and always hit bottom end down, thus standardizing impact location and facilitating the evaluation of bruising and pitting damage. Five replications of 15 fruit were used at each temperature. After impact, cherries were stored at $20^{\circ} \mathrm{C}\left(68^{\circ} \mathrm{F}\right)$ for 2 days before bruising was measured (1991 season) or at $1^{\circ} \mathrm{C}\left(34^{\circ} \mathrm{F}\right)$ for 14 days before pitting was measured (1993 season), then moved to $24^{\circ} \mathrm{C}\left(75^{\circ} \mathrm{F}\right)$ for 2 days before evaluation. Bruising injury (more than $2.0 \mathrm{~mm}$ in diameter or $3.1 \mathrm{~mm}^{2}$ ) was determined by external color and internal color and textural changes. Pitting was evaluated externally as flattened and/or darkened places, or as pits greater than $3.1 \mathrm{~mm}^{2}$ on the surface of the cherry.

\section{Temperature effects}

\section{Respiration rate. $\mathrm{CO}_{2}$} production rate increased with temperature in all cultivars tested (fig. 1). 'Bing' cherries produced less $\mathrm{CO}_{2}$ than 'Brooks,' 'Tulare' and 'King' at each temperature. Respiration rates were similar among 'Brooks,' 'Tulare' and 'King' cherries at $0^{\circ}, 5^{\circ}$ and $10^{\circ} \mathrm{C}\left(32^{\circ}, 41^{\circ}\right.$ and $\left.50^{\circ} \mathrm{F}\right)$. At $20^{\circ} \mathrm{C}\left(68^{\circ} \mathrm{F}\right)$, 'Brooks' had a lower respiration rate than either 'Tulare' or 'King,' but a higher respiration rate than 'Bing.' Carbon dioxide production was 45 to $55 \mathrm{mg} \mathrm{CO} / \mathrm{kg} /$ hr at $20^{\circ} \mathrm{C}\left(68^{\circ} \mathrm{F}\right)$ for 'Brooks,' 'Tulare' and 'King,' suggesting that they may be more susceptible to rapid deterioration than 'Bing' ( $35 \mathrm{mg} \mathrm{CO} 2 / \mathrm{kg} / \mathrm{hr}$ at $20^{\circ} \mathrm{C}$.

Impact damage. Flesh temperature at the time of impact significantly affected bruising incidence $(P=0.001)$. Internal and external bruising damage decreased as temperature increased (fig. 2). The incidence of impact bruis-

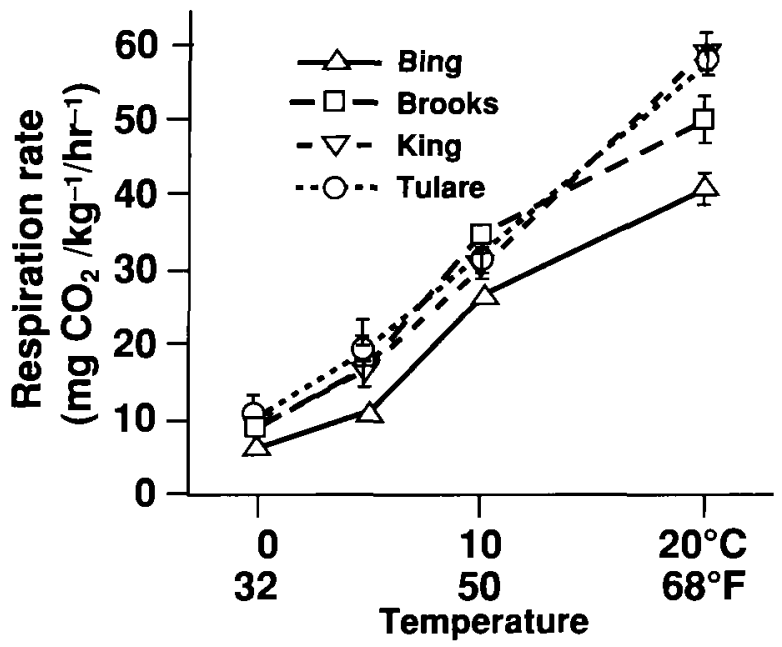

Fig. 1. Respiration rates of 'Bing,' 'Brooks,' 'Tulare' and 'King' cherry cultivars measured at $0^{\circ}, 5^{\circ}$ and $10^{\circ} \mathrm{C}\left(32^{\circ}, 41^{\circ}\right.$ and $68^{\circ} \mathrm{F}$ ). Bars indicate standard error.

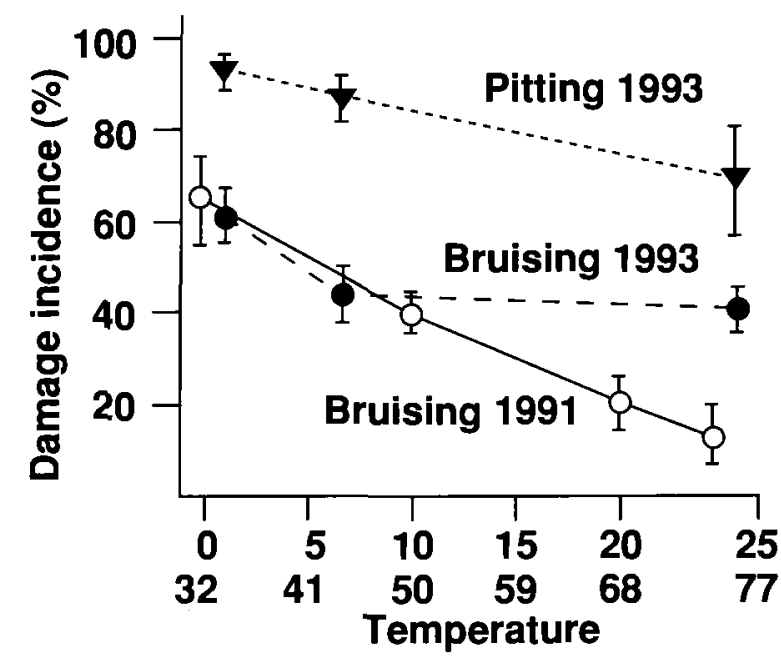

Fig. 2. Relationship between cherry flesh temperature and damage susceptibility (\% of fruit damaged) for 'Brooks' cherry during the 1991 and 1993 seasons. Bars indicate standard error. ing damage was higher when the flesh temperature was less than $10^{\circ} \mathrm{C}\left(50^{\circ} \mathrm{F}\right)$.

Surface pitting. 'Brooks' flesh temperature at the time of impact significantly affected surface pitting ( $\mathrm{P}=$ $0.001)$ and bruising $(P=0.040)$. Pitting damage decreased as cherry temperature increased for this cultivar (fig. 2). Impact that occurred when flesh temperature was $1^{\circ} \mathrm{C}\left(34^{\circ} \mathrm{F}\right)$ induced significantly higher pitting damage levels than impact that occurred at $7^{\circ} \mathrm{C}\left(44^{\circ} \mathrm{F}\right)$ or $26^{\circ} \mathrm{C}\left(78^{\circ} \mathrm{F}\right)$ flesh temperature. Also, significant differences in severity of pitting occurred between $7^{\circ}$ and $26^{\circ} \mathrm{C}$ $\left(44^{\circ} \mathrm{F}\right.$ and $\left.78^{\circ} \mathrm{F}\right)$. Bruising was always higher on cold than on warm cherries (fig. 2). Bruising levels and the relationship between temperature and bruising severity were similar in the 1991 and 1993 studies.

\section{Recommendations}

'Brooks' cherries handled at temperatures near $1^{\circ} \mathrm{C}\left(34^{\circ} \mathrm{F}\right)$ suffer more pitting and bruising damage than those handled at temperatures above $10^{\circ} \mathrm{C}\left(50^{\circ} \mathrm{F}\right)$. Therefore, cooling can be done just before package filling (in-line hydrocooler) or by forced-air cooling soon after packaging. The new cherry cultivars ('Brooks,' 'King' and 'Tulare') had almost double the respiration rate of 'Bing' cherries at $20^{\circ} \mathrm{C}\left(68^{\circ} \mathrm{F}\right)$; therefore they should be cooled to $0^{\circ} \mathrm{C}\left(32^{\circ} \mathrm{F}\right)$ within 4 hours after harvest to reduce their deterioration rates and maximize postharvest life.

C.H. Crisosto is Postharvest Physiologist and D. Garner is Staff Research Associate, Pomology Department, UC Davis; H. Andris and K.R. Day are Farm Advisors, Cooperative Extension, Fresno and Tulare counties, respectively. 